\title{
Impact on the Performance of Search and Rescue Team by Cloud-Based Services: A Case Study of TransAsia Flight GE235
}

\author{
Yan-Kai Fu' ${ }^{1}$, Chia-Chiang Lee ${ }^{2}$ and Weilun Huang \\ ${ }^{1}$ Department of Aviation Services and Management, China University of Science and Technology, Taiwan \\ ${ }^{2}$ Institute of Applied Technology, National Taiwan University of Science and Technology, Taiwan \\ ${ }^{3}$ School of Finance, Wenzhou Business College, China
}

\begin{abstract}
The purpose of this study is to determine the significant gap between the suitable objective environmental conditions and the real performance outcomes when Taipei fire fighter officers and volunteer fire fighters handled the TransAsia GE235 incident. This study employs the "Unified Theory of Acceptance and Use of Technology (UTAUT)" model to investigate the search and rescue (SAR) team members' adoption of cloud-based services to improve their SAR performance. This study uses the Partial Least Square (PLS) validation for the research hypotheses. The results show that the Taipei City Fire Department's SAR team and the Volunteer Fire Fighter team have certain gaps in applying the cloud-based service to improve the incident SAR performance. It is revealed that resources, especially in training/education of the government official team, are significant to performance improvement. Finally, several management implications are presented to improve the SAR operation performance.
\end{abstract}

\section{Introduction}

In early 2015, people in Taiwan were preparing for the coming lunar New Year holiday when TransAsia Airways Flight 235 (GE235/TNA235, a domestic flight) crashed into the Keelung River at 10:50 am (T hour), on 4 February 2015, shortly after takeoff from Taipei Song Shan Airport, which was $5.4 \mathrm{~km}$ to the west. In this major incident, there was a very significant problem: government authorities had invested a huge amount of the budget to the cloud service for SAR operations. Bureaucrats had proper training for the cloud-based service, and most of the people involved in this incident had the devices required to run the cloud-based applications. The responders were well prepared to use the cloud-based service to improve the performance of SAR operations; however, this incident indicates otherwise. The chaotic situation from the incident $\mathrm{T}-0$ hours until days later remained almost the same.

The past, research related to aviation safety, regardless of the human factor approach ([1], [12], [29]), SAR operation approach ([21]), aviation incident prediction approach ([4], [15]) and relevant incident management approach ([14], [30]), all focused mainly on safety precautions or incident predictions. Even the cloud-based technology, which has been in service for a decade, and how to apply this new technology in incident SAR operations have only been studied at the theoretical level ([31]). There is no research on an actual case in which cloud services were adopted to improve the performance of SAR operations when an incident occurs.
The primary motivation for this paper is the observed full utilization of cloud-based services by the team members who were involved in the SAR operation of an incident, so the purpose of this study is to explore the gap between the technology and the humans who were involved in this SAR operation by using the Unified Theory of Acceptance and Use of Technology (UTAUT) model. The differences between this study and past studies lie in three areas: volunteer fire fighters, information-communication-technology (ICT), and the actual SAR operation involved in this major urban aviation incident. The cloud-based services include a mixture of hardware (smartphone), software (e.g., LINE, Google) and telecommunication (Wi-Fi, e-mail, cellular phones, and mobile internet).

Cloud-based services have been part of the public safety (PS) domain, for the management of crisis and disaster is to reduce the impact and injury to individuals, assets and society, and it requires a set of capabilities, including communication, resource management, supply chain management and access to relevant data sources. Communication is an essential element in various operational scenarios and at different levels of the hierarchy of PS organizations. First responders should be able to exchange information (i.e., voice and data) in a timely manner to coordinate relief efforts and improve the situational awareness of the environment. (Baldini, et al., 2011).

Currently, many user acceptance models with different determinants exist to measure the user agreement in information systems, which is an important

\footnotetext{
a Corresponding author: huangwl@wzbc.edu.cn
} 
factor for indicating system success or failure ([17]). Each theory or model has been widely tested to predict user acceptance ([28]). However, no comprehensive instrument to measure the variety of perceptions of information technology innovations existed until Venkatesh et al. ([28]) attempted to review and compare the existing user acceptance models, with the ultimate goal of developing a unified theory of technology acceptance by integrating every major parallel aspect of user acceptance determinants from those models. The results from the UTAUT model explained seventy percent $(70 \%)$ of the variation in users' intention to accept technology ([28]). The eight original models and theories of individual acceptance synthesized by Venkatesh et al. ([28]) include the Theory of Reasoned Action (TRA), Technology Acceptance Model (TAM), Motivational Model (MM), Theory of Planned Behavior (TPB), Model Combining the Technology Acceptance Model and Theory of Planned Behavior (C-TAM-TPB), Model of PC Utilization (MPCU), Innovation Diffusion Theory (IDT), and Social Cognitive Theory (SCT). ([23], [5-8], [18] [23-28])

From the above discussion, this study attempt to apply the UTUAT theory and extant factors that influence the behavioral intention when an incident SAR operation is executed. The rest of this paper is organized as follows: In Section 2, the hypothesis and statistical results are discussed. Section 3 describes and analyzes the results are used to validate the hypothesis. Section 4 gives the conclusions and the outline of future works.

\section{The hypothesis and statistical results}

This study uses the research framework (see Figure 1) which included the four main dimensions of UTAUT: Performance Expectancy (PE), Effort Expectancy (EE), Social Influence (SC), and Facilitating Conditions (FC). The major differences between this research framework and the original UTAUT model lie in the temporal dimension and the connotation of determinants by "external variables". Regarding temporal dimension, because Venkatesh et al. ([28]) used specific application software to train the same participant, which required three tests in three periods before and after training. Additionally, this paper only discusses the relationship among external variables, behavioral intention, and use behavior; the control variable is not discussed.

According to the UTAUT model, the research framework of this study was modified, and the research hypotheses were proposed as follows:

H1 - A participant who uses the cloud-based application/service expects that "performance expectancy" will increase the "behavioral intention" of cloud-based application/service adoption in a SAR operation.

H2 - A participant who uses the Cloud-Based Application/Service expects that "effort expectancy" will increase the "behavioral intention" of cloud-based application/service adoption in a SAR operation.

H3 - A participant who uses the Cloud-Based Application/Service expects that "social expectancy" will increase the "behavioral intention" of Cloud-Based Application/Service adoption in a SAR operation.

H4 - A participant who uses the Cloud-Based Application/Service expects that "facilitating conditions" will increase the "behavioral intention" of Cloud-Based Application/Service adoption in a SAR operation.

H5 - A participant who uses the Cloud-Based Application/Service expects that "behavioral intention" will increase the "use behavior" of Cloud-Based Application/Service adoption in SAR operation.

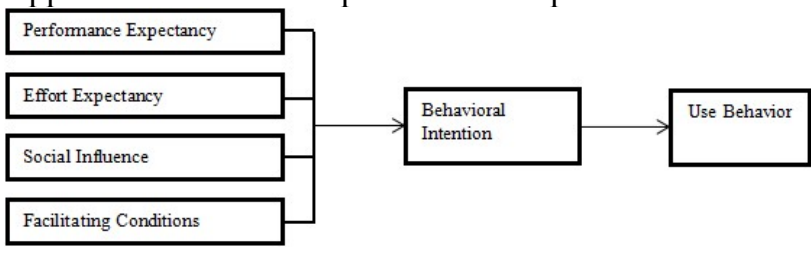

Figure 1. Research framework.

The on-site survey approach was used to complete the resulting questionnaire. The demographic data showed that 57 subjects $(76.0 \%)$ were Taipei fire fighter officers, indicating that the percentage of Taipei fire fighter officers was much higher than the percentage of volunteer fire fighters among those responding to the survey. The sample included 23 subjects between the ages of 26 and $35(30.7 \%)$ and 20 subjects between the ages of 36 and $45(20.0 \%)$. Half of the subjects $(50.7 \%)$ were between the ages of 26 and 45 . The data revealed that 36 subjects $(48.0 \%)$ had a college background and that 25 subjects $(33.3 \%)$ had a university background. Most of the subjects were not aware of government cloud services or were not very aware of government cloud services, numbering $33(44.0 \%)$ and 17 (22.7\%), respectively.

Table 1 provides a summary of the source of each UTAUT construct; the study uses the definition from Venkatesh et al. ([28]) to consider the characteristics of the aviation SAR operation and selects proper items to measure search and rescue team members' awareness of each construct measure. These relationships include Effort Expectancy (EE), Performance Expectancy (PE), Social Influence (SI), and Facilitating Conditions (FC) predicting Behavioral Intention (BI), which influence Use Behavior (UB).

Table 1. Items of UTAUT variables.

\begin{tabular}{|c|c|c|}
\hline Construct & $\begin{array}{c}\text { Operational } \\
\text { Definitions }\end{array}$ & Items \\
\hline $\begin{array}{l}\text { Performance } \\
\text { Expectancy }\end{array}$ & $\begin{array}{l}\text { The degree } \\
\text { that the } \\
\text { participant } \\
\text { believes that } \\
\text { using the } \\
\text { Cloud-based } \\
\text { Application/S } \\
\text { ervices can } \\
\text { improve work } \\
\text { performance }\end{array}$ & $\begin{array}{l}\text { PE1 I think Cloud-based } \\
\text { Application/Services can } \\
\text { support communication- } \\
\text { related activities. } \\
\text { PE2 Cloud-based } \\
\text { Application/Services can } \\
\text { help me improve search and } \\
\text { rescue operation efficiency. } \\
\text { PE3 When I was executing } \\
\text { the search and rescue } \\
\text { operation, Cloud-based } \\
\text { Application/Services could } \\
\text { be used. } \\
\text { PE4 In general, Cloud-basec }\end{array}$ \\
\hline
\end{tabular}




\begin{tabular}{|c|c|c|}
\hline & & $\begin{array}{l}\text { Application/Services can } \\
\text { satisfy me throughout the } \\
\text { search and rescue operation. }\end{array}$ \\
\hline $\begin{array}{c}\text { Effort } \\
\text { Expectancy }\end{array}$ & $\begin{array}{l}\text { The degree of } \\
\text { ease } \\
\text { associated } \\
\text { with } \\
\text { participant's } \\
\text { use of Cloud- } \\
\text { based } \\
\text { Application/S } \\
\text { ervice }\end{array}$ & $\begin{array}{c}\text { EE1 I understand what } \\
\text { Cloud-based } \\
\text { Application/Services are. } \\
\text { EE2 I can use Cloud-based } \\
\text { Application/Services during } \\
\text { search and rescue operation- } \\
\text { related activities. } \\
\text { EE3 Using Cloud-based } \\
\text { Application/Services is not } \\
\text { difficult. } \\
\text { EE4 Learning how to install } \\
\text { and setup Cloud-based } \\
\text { Application/Services is not } \\
\text { difficult. }\end{array}$ \\
\hline $\begin{array}{c}\text { Social } \\
\text { Influence }\end{array}$ & $\begin{array}{l}\text { The degree to } \\
\text { which } \\
\text { participants } \\
\text { perceive that } \\
\text { others close to } \\
\text { them (e.g., } \\
\text { family and } \\
\text { friends) } \\
\text { believe they } \\
\text { should use a } \\
\text { particular } \\
\text { technology }\end{array}$ & $\begin{array}{l}\text { SI1 People who influence } \\
\text { my behavior think that I } \\
\text { should use Cloud-based } \\
\text { Application/Services. } \\
\text { SI2 People who are } \\
\text { important to me think that I } \\
\text { should use Cloud-based } \\
\text { Application/Services. } \\
\text { SI3 In general, the Taipei } \\
\text { Fire Department has } \\
\text { supported the use of Cloud- } \\
\text { based Application/Services. }\end{array}$ \\
\hline $\begin{array}{l}\text { Facilitating } \\
\text { Conditions }\end{array}$ & $\begin{array}{l}\text { The degree to } \\
\text { which } \\
\text { participants } \\
\text { believe that an } \\
\text { organization- } \\
\text { al and } \\
\text { technical } \\
\text { infrastructure } \\
\text { exists to } \\
\text { support the } \\
\text { use of a } \\
\text { particular } \\
\text { system }\end{array}$ & $\begin{array}{c}\text { FC1 I have the resources } \\
\text { necessary to use Cloud- } \\
\text { based Application/Services. } \\
\text { FC2 I have the knowledge } \\
\text { necessary to use Cloud- } \\
\text { based Application/Services. } \\
\text { FC3 It is easy to acquire the } \\
\text { Cloud-based } \\
\text { Application/Services-related } \\
\text { knowledge. } \\
\text { FC4 A specific person } \\
\text { (resources or group) is } \\
\text { available for assistance with } \\
\text { Cloud-based } \\
\text { Application/Service } \\
\text { difficulties. }\end{array}$ \\
\hline $\begin{array}{l}\text { Behavioral } \\
\text { Intention }\end{array}$ & $\begin{array}{l}\text { The degree to } \\
\text { which } \\
\text { participants } \\
\text { are willing to } \\
\text { use Cloud- } \\
\text { based } \\
\text { Application/S } \\
\text { ervices }\end{array}$ & $\begin{array}{c}\text { BI1 I would like to use } \\
\text { Cloud-based } \\
\text { Application/Services during } \\
\text { daily activities. } \\
\text { BI2 When application } \\
\text { software and hardware are } \\
\text { ready, I like to use Cloud- } \\
\text { based Application/Services } \\
\text { during a search and rescue } \\
\text { operation. }\end{array}$ \\
\hline Use Behavior & $\begin{array}{c}\text { How often } \\
\text { participants } \\
\text { actually use } \\
\text { Cloud-based } \\
\text { Application/S } \\
\text { ervices }\end{array}$ & $\begin{array}{c}\text { The actual number of times a } \\
\text { participant uses Cloud-based } \\
\text { Application/Services }\end{array}$ \\
\hline
\end{tabular}

\section{The results}

This study employs partial least squares (PLS), which performed by the SmartPLS software, a technique for analyzing or constructing predictive models, especially for a causal model analysis of potential variables over LISREL. Since there are few samples in this study, PLS is not limited by the number of variables assigned or the number of samples, and it has a good ability of prediction and interpretation. Because the sample size is not large, the bootstrap resampling method is repeatedly used to extract 1,000 samples for parameter estimation and inference. ([20], [22])

When using partial least squares (PLS) data analysis, the first step is to test the reliability and validity of the measurement model, and the second step is to detect the structural model of the path coefficient significance and its ability to predict. According to Table 2, the reliability of each construct reached an acceptable level of 0.7 or greater, indicating that the questionnaire items in this study have good reliability. The CR values of all constructs in this study ranged from 0.821 to 0.948 , all of which were in the standard range of 0.6 or above, indicating that the scale of this study has a good composite reliability. The AVE values of all constructs in this study range from 0.607 to 0.820 , all of which are above the standard AVE value of 0.5 ; therefore, they have good convergence validity. ([9], [11], [13], [16], [19]).

Table 2. Reliability analysis.

\begin{tabular}{|c|c|c|c|}
\hline Construct & Cronbach's $\alpha$ & CR & AVE \\
\hline $\begin{array}{c}\text { Performance } \\
\text { Expectancy }\end{array}$ & 0.878 & 0.905 & 0.706 \\
\hline $\begin{array}{c}\text { Effort } \\
\text { Expectancy }\end{array}$ & 0.927 & 0.948 & 0.820 \\
\hline Social Influence & 0.877 & 0.904 & 0.762 \\
\hline $\begin{array}{c}\text { Facilitating } \\
\text { Conditions }\end{array}$ & 0.919 & 0.913 & 0.724 \\
\hline $\begin{array}{c}\text { Behavioral } \\
\text { Intention }\end{array}$ & 0.780 & 0.821 & 0.607 \\
\hline Use Behavioral & 0.747 & 0.828 & 0.620 \\
\hline
\end{tabular}

In this study, the Bootstrap method was used to repeatedly extract 1,000 samples to verify the relationship and significance of path coefficients in the structural model. In terms of the influence on Behavioral Intention, from the results of the path analysis in Figure 2, Performance Expectancy $(\beta=0.684, \quad t$-value $=4.427)$, Facilitating Conditions $(\beta=0.466, t$-value $=2.453)$, and Social Influence $(\beta=0.345, \mathrm{t}$-value $=3.177)$ all had a significant positive influence on Behavioral Intention (BI). Hypotheses $\mathrm{H} 1, \mathrm{H} 3$ and $\mathrm{H} 4$ are thus supported. Effort Expectancy $(\beta=0.079$, t-value $=0.282)$ has no significant positive influence on Behavioral Intention, so $\mathrm{H} 2$ is not supported. In addition, Behavioral Intention ( $\beta$ $=0.781, \mathrm{t}$-value $=6.059$ ) has a significant positive influence on Use Behavior; therefore, $\mathrm{H} 5$ is supported.

From Figure 2, the $R^{2}$ values for Behavioral Intention and Use Behavior are, respectively, $68.0 \%, 74.7 \%$, indicating that the study model has good explanatory power. The solid line indicates that the $p$-value is significant, and the dotted line indicates that the p-value is not significant. To further compare the difference of demographic variables between Behavioral Intention and Use Behavior (See Table 3). 


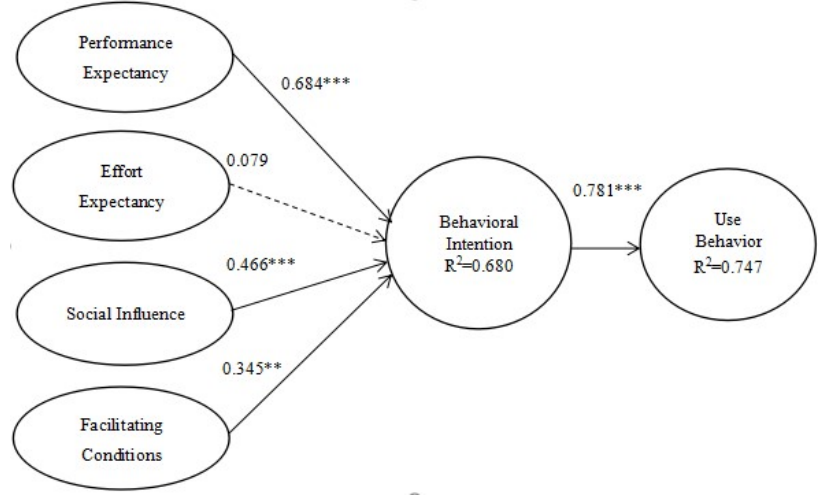

Figure 2. The results on the path of model.

Performance expectancy has a significant positive influence on behavioral intention, indicating that users' impact on job performance will directly affect their behavioral intentions toward the new system after the importation of the cloud-based service technologies that are currently used. Therefore, the management unit should, in addition to training uses on a system during the training period, further enhance the explanation of the performance and other benefits that can be gained after the system itself is used to improve the user's perception of performance expectancy, thereby enhancing their behavioral intention.

Facilitating conditions have a significant positive influence on behavioral intention, indicating that users perceive the extent of their own resources (including those provided by the supervisor and their own) that affect their behavioral intentions. Therefore, in addition to providing users with proper education and training so they have their own capabilities, the management unit should combine all necessary resources and advocate for the user to understand and design a simpler and more convenient and easy-to-use system so users have no doubts about the use of the cloud-based service system and increase their perception of the system's convenience, thereby enhancing their behavioral intention.

Social influence has a significant positive influence on behavioral intention, indicating that users' perception of the use of cloud-based services by their peers, bosses, and friends affects their behavioral intentions. Therefore, after the introduction of the system, the management unit should conduct a simple follow-up observation of the user's use behavior. If there is any resistance or other negative attitudes toward the cloud-based service, the management unit should communicate with the individual to reduce the negative attitude toward the system expansion, which can enhance the overall behavioral intention.

To improve the user's actual use behavior of the new system and further improve the system's efficiency, the supervisory unit should strengthen the quality and quantity of education and training during the process of introducing the new system. In addition to providing complete and clear training for use, users should be made aware of the system's benefits and increase their chances of practicing prior to actual use, thus increasing the users' awareness of performance expectancy and facilitating the conditions and social influence of the system. Additionally, supervisors should increase their use of flexible or individual user guidance or use learning methods to share their experiences with peers to enhance use behavior.

\section{Conclusion}

Most modern SAR operations have incorporated cloudbased services into their activities, with the aim of achieving higher efficiency and improving productivity, which in turn leads to higher satisfaction (Attuquayefio, 2014). Every participant must be willing and ready to apply cloud-based services in major incidents to improve the SAR operation performance. However, the results show that actual attitudes toward adapting cloud-based services is not equal between government officers and volunteers. This is obviously because the Taipei fire department is the official unit that can access the cloudbased services and has access to the most resources to adapt to any kind of incident.

This finding shows that the government must invest more promotion, education and training into the cloudbased service that already exists. To cover the digital gap between these groups, the government must pay for more training-related resources for the volunteer section. The government needs volunteers as a resource to supplement its direct work force; therefore, the volunteer section requires government funding that includes training.

The major contribution of this study is providing an understanding of the gaps in new technology adaption and the differences between different identities and education. The results show that the incident SAR operations do occur occasionally, especially in Taiwan, whose residents are forced to deal with extreme natural disasters, including typhoons and earthquakes. Over the past decade, global warming has caused stronger and longer typhoon seasons, stronger winter seasonal wind, and temperature drops. The correct approach must be applied to this type of objective situation, including intensive training/exercise. In other words, by using a real government cloud service, the related unit/individual can share different user experiences to improve the system optimization from the user interface to the core database/application system. The TransAsia GE235 incident in particular provides a field case to test the new cloud-based technology by applying the UTAUT model in a new scenario.

The research objective of this study is only aimed to examine the actual participation of disaster victims in this crash incident. There are some limitations to the availability and source of samples. We suggest that future research should use a case-based interview or a focus group interview to discuss the incident in greater depth.

Although the UTAUT Model is used in this study for practical analysis, it is not included in the discussion of control variables. It is suggested that future research discuss individual control variables; other models and potential construct variables may also be considered to help identify the key factors and the causal relationship in the model. 
Practical use behavior, although a directly observable variable, is often affected by other external variables, which increases the difficulty of measurement. It is suggested that the future research consider as many external factors as possible to measure the actual use behavior and design suitable moderating factors to present the actual behavior that is influenced by the potential constructs.

\section{References}

1. Adjekum D.K., Keller J., Walala M., Young J.P., Christensen C., DeMik R.J., Northam G.J. CrossSectional Assessment of Safety Culture Perceptions and Safety Behavior in Collegiate Aviation Programs in the United States. Int. J. Aviation. Aeron, 2(4) (2015)

2. Ajzen, I. Organizational behavior and human decision processes. Theories of Cognitive SelfRegulation, 50(2), 179-211 (1991)

3. Bandura, A. Social foundations of thought and action. Prentice Hall, Englewood Cliffs, NJ. (1986)

4. Chen Y.G., Ren H.F. Application of gray Markov model in aviation incident prediction. J. Xian. U. Sci. Technol., 02 (2007)

5. Compeau R.D., Higgins A.C. Computer SelfEfficacy: Development of a Measure and Initial Test. MIS. Quart., 19, 189-211 (1995)

6. Davis F.D. Perceived usefulness, perceived ease of use, and user acceptance of information technology. MIS. Quart., 13, 319-340 (1989)

7. Davis F.D., Bagozzi R.P., Warshaw P.R. Extrinsic and Intrinsic Motivation to Use Computers in the Workplace. J. Appl. Soc. Psychol., 22(14), 11111132 (1992)

8. Fishbein M., Ajzen I., Belief, attitude, intention, and behavior: an introduction to theory and research. Reading, MA: Addison-Wesley, (1975)

9. Fornell C., Larcker D.F. Evaluating structural equation models with unobservable variables and measurement error. J. Marketing. Res., 18(1), 39-50 (1981)

10. Hair F.H., Hult GTM, Ringle C.M., Sarstedt M. A primer on partial least squares structural equation modeling (PLS-SEM). Thousand Oaks: Sage Publications, (2014)

11. Harizi R., Belhaiza M.A., Harizi B. A Cliometric Analysis of the Explanatory Factors of the Air Crashes in the World (1950-2008). J. Transp. Saf. Secur., 5(2), 165-185 (2013)

12. Hulland J. Use of Partial Least Squares (PLS) in Strategic Management Research: A Review of Four Recent Studies. John Strategic Mana. J., 20(2), 195204 (1999).

13. Li Y., Zhang X.Q. Application of Grey Correlation Analysis in Civil Aviation Incidents Management, Technology. Ec. Areas, 2011-03 (2011)

14. Liu L.L., Sun Y.F. Prediction Model of the Air Transport Incidents of Civil Aviation Based on Set Pair Analysis, Safety. Env. Eng., 2013-05 (2013)
15. Medina M.Q., Chaparro J.P., The impact of the human element in the information systems quality for decision making and user satisfaction. J. Comput. Inform. Syst., 48(2), 44-53 (2007/2008)

16. Melone N.P. A Theoretical Assessment of the UserSatisfaction Construct in Information Systems Research, Manage. Sci., 36(1), 76-91 (1990)

17. Moore G.C., Benbasat I. Development of an instrument to measure the perceptions of adopting an information technology innovation. Inform. Syst. Res., 2, 192-222 (1991)

18. Pavlou P.A., Fygenson, M. Understanding and predicting electronic commerce adoption: An extension of the theory of planned behavior. MIS. Quart., 30(1), 115-143 (2006).

19. Pirouz D.M. An overview of partial least squares. The Paul Merage School of Business University of California, (2006)

20. Ramstad R., Rake O.N., Braut G.S., Incident Command and Information Flows in a Large-Scale Emergency Operation. J. Conting. Crisis. Man., 22(1), 29-38 (2014)

21. Ringle C.M., Wende S., Will A. Smart PLS 2.0 M3. Hamburg: University of Hamburg. www.smartpls.de, (2005)

22. Rogers E.M. Diffusion of innovations (3rd Ed.). New York: Free Press, (1983)

23. Taylor S., Todd P.A. Decomposition and Crossover Effects in the Theory of Planned Behavior: A Study of Consumer Adoption Intentions. Int. J. Res. Mark., 12(2), 137-155 (1995)

24. Taylor S., Todd P.A. Understanding Information Technology Usage: a Test of Competing Models. Inform. Syst. Res., 6(2), 144-176 (1995)

25. Thompson R.L., Higgins C.A., Howell J.M. Personal Computing: Toward a Conceptual Model of Utilization. MIS. Quart., 15(1), 125-143 (1991)

26. Venkatesh V., Davis F.D. A Theoretical Extension of the Technology Acceptance Model: Four Longitudinal Field Studies. Manage. Sci., 46(2), 186204 (2000)

27. Venkatesh V., Morris M.G., Davis G.B., Davis F.D. User Acceptance of Information Technology: Toward a Unified View. MIS Quart., 27(3), 425-478 (2003)

28. Vine S.J., Uiga L., Lavric A., Moore L.J., TsanevaAtanasova K., Wilson M.R. Individual reactions to stress predict performance during a critical aviation incident. Anxiety. Stress. Copin., 28(4), 467-477 (2015)

29. Wallace R.J. Effect of Cellular Phone and Radar Forensics on Search and Rescue Duration for General Aviation Aircraft Accidents in the Contiguous United States. J. Aviat. Technol. Eng., 3(2), Article 7 (2014)

30. Wang J., Rosca D., Tepfenhart W., Milewski A., Stoute M. Dynamic workflow modeling and analysis in incident command systems. IEEE. T. Syst. Man. Cy. A., 38(5), 1041-1055 (2008) 